\title{
Efeito da vacinação estreptocócica sobre a produção de antiestreptofibrinolisina
}

\author{
por \\ J. Guilherme Lacorte e Mario Santos
}

Os estudos de Tillett e Garner sôbre a obtenção de um fator fibrinolitico produzido pelo estreptococo hemolitico abriu um novo e interessante capitulo referente, não só à interpretação de alguns processos patológicos ocasionados pelo germe em questão, como também sôbre nova reação de imunidade com caráter específico e aplicada à clínica por Furcolow e Fousek. De 1936 até hoje muitos trabalhos foram feitos mostrando-nos as vantagens que podemos auferir trazendo para a prática os resultados dessas pesquisas, conforme fizeram Bau e Klen para a escarlatina, Rantz e Kirty para a pesquisa do título de antiestreptofibrinolisina em portadores de germes ou não e Boisvert em outras interpretações clinicas.

Desde 1940 vimos trabalhando com amostras de estreptococo hemolítico, obtidas de infecções humanas e todas com atividade fibrinolitica. A verificação dessa atividade foi feita sempre em relação ao plasma humano e nossas experiências versaram, principalmente, sôbre a influência da fibrinolisina na patogenia do abcesso periamigdaliano e na correlação que existe entre a presença do anticorpo correspondente a outras infecções por estreptococo hemolitico.

Alguns ensaios foram feitos então para, com facilidade, comprovar as nossas conclusões ou reforçar as afirmativas de outros autores.

Com esse intuito tomamos a deliberação de verificar a influência da vacinação sôbre o poder antiestreptofibrinolítico do plasma de indivíduos considerados indenes de infecção estreptocócica recente e, sobretudo, sem passado reumático, onde verificações de Walker \& Chester, Waller e Burnin \& Mc Ewen concluiram pela sua presença.

Vacinamos 5 pessoas cada uma com diferente amostra de estreptococo hemolítico, cuja atividade fibrinolitica foi previamente verificada. O plasma de cada individuo foi dosado duas vezes com o fim de verificar o seu poder antifibrinolitico e em relação à fibrinolisina de 8 amostras diferentes, entre as

- Recebido para publicação em Dezembro de 1946. 
quais as 5 empregadas nas vacinações. A primeira dosagem foi feita antes do início da vacinação e a segunda 8 dias após a aplicação da última dose de vacina. Em todos os casos foram feitas 7 injeções desta, com intervalo de 3 dias entre cada uma. As amostras de estreptoco hemolitico usadas nas experiências têm as seguintes indicações:

$\begin{array}{ll}\text { N. }^{\circ} & \text { Isolada de material colhido de: } \\ 2 & \text { lesões de erisipela } \\ 13 & \text { pús de abcesso de amigdala } \\ 16 & \text { pús de abcesso subcutaneo } \\ 21 & \text { pús de abcesso de amigdala } \\ 22 & \text { pús de abcesso e amigdala } \\ 24 & \text { pús de abcesso de amigdala } \\ 25 & \text { pús de abcesso de amigdala } \\ 27 & \text { lesões de erisipela }\end{array}$

Para o preparo da vacina foram os germes semeados no meio de Garner e Tillett que assim se prepara :

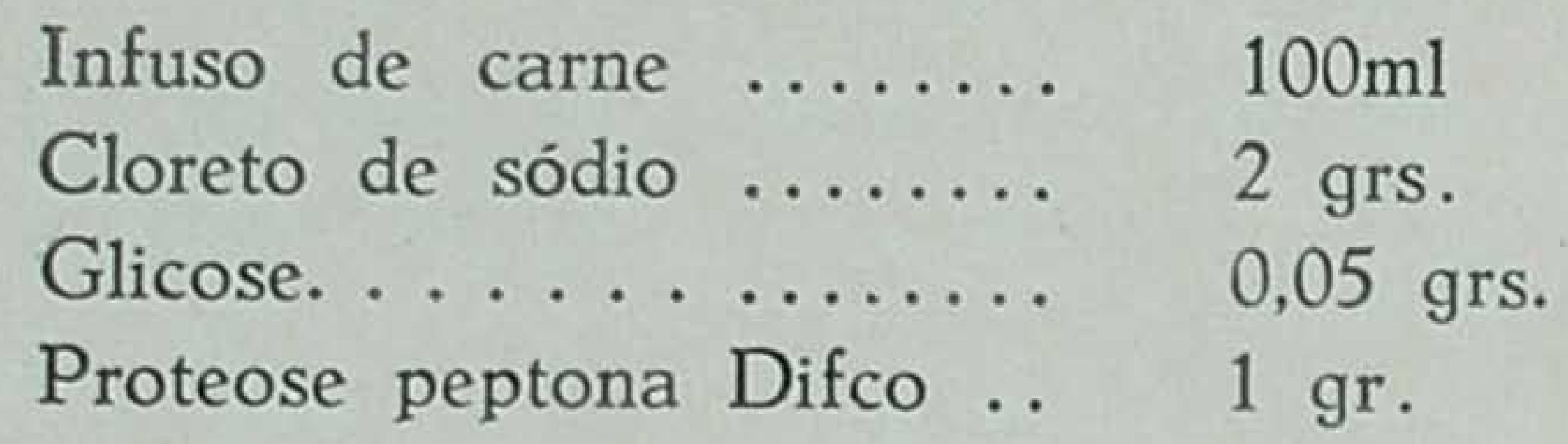

Depois de dissolver, ajustar o $\mathrm{pH}$ a 7,4 sem adicionar tampão. Distribuir e esterilizar no autoclave segundo a técnica usual.

As culturas são incubadas de 14 a 18 horas a $37 .^{\circ}$. Centrifuga-se e os germes colhidos do fundo do tubo são suspensos em agua fisiologica e de novo centrifugados e assim algumas vezes, com o fim de lavá-los. A seguir, são mortos pelo calor a $65-70^{\circ} \mathrm{C}$, durante 1 hora. Procede-se, depois, à suspensão em agua fisiológica fenicada a 5 por mil para o preparo da vacina em doses de 50 a 500 milhões de germes por cc.

Para verificar a presença da antifibrinolisina colhemos, em citrato de sódio, o sangue das pessoas que se prestaram a estas experiências, separamos o plasma e procedemos a reação juntando a $1 \mathrm{cc}$. do plasma diluido em agua fisiológica a 1:5,0,5 cc. do filtrado de cultura cle estreptococos. Este filtrado foi obtido pela centrifugação da cultura feita conforme a técnica acima des crita para o preparo da vacina e passagem atravez vela de porcelana. Agitamos a mistura, juntamos 0,25 da solução de cloreto de cálcio a $0,25 \%$ e levamos os tubos ao banho maria a $37,5 \mathrm{C}$. Começamos a contar o tempo de lise a partir da coagulação do plasma e medimos a atividade antifibrinolítica pela resistência que o plasma oferece à estreptofibrinolisina. Consideramos resistente o plasma que ao fim de 20 horas não foi liquefeito. 
Os resultados das nossas experiências permitiu-nos chegar à seguinte conclusão :

A vacinação com estreptococos hemoliticos, utilizando germes lavados, não confere ao plasma do vacinado resistência à fibrinólise, quando sôbre êle atúa a estreptofibrinolisina.

Este fato leva-nos a crêr que a fibrinolisina é soluvel no meio de cultura e que a formação da antifibrinolisina depende da sua presença, não sendo suficiente somente a presença do estreptococo.

Este fato tem importancia prática no preparo do soro antiestreptococico que deverá ser também antifibrinolítico, além de antibacteriano e antitóxico.

\section{SUMMARY AND CONCLUSIONS}

The vaccination with hemolytic streptococci washed in saline doesn't give to the plasma of vaccinated people resistence against fibrinolysis, when in presence of antistreptofibrinolysin.

The A. A. believe that the fibrinolysin in solube is the culture medium and that it is necessary to the formation of the antifibrinolysin. This fact is important in the preparation of the antistreptococcal serum which must be antibacterian, antitoxic and antifibrinolytic.

\section{BIBLIOGRAFIA}

BAU, C. A. \& KLEN, N.

1936. Ueber Fibrinolyse und Fibrinolysehemmung in Plasma im verlauf des Scharlachs. Cent. f. Bakt. 136, 289.

BOISVERT, P.

1940. The streptococcal antifibrinolysin test in clinical use. J. Clin. Inv. 19,65.

Bunim, J. \& Mc Ewen, C.

1940. The antistreptolysin titer in rheumatic fever arthritis and other diseases. J. Clin. Inv. 19, 75.

Furcolow, L. \& Fousek, D.

1936. Streptococcal antifibrinolysin test in clinical use. J. Bact. 31, 102.

Rantz, J. A. \& Kirty, W.

1943. Group A hemolytic streptococcus antibodies. II. Griffith type agglutinin and antistreptolysin titers in carriers and non carriers. J. Clin. Inv. 22, 419.

Tillett, W. S. E Garner, R. L.

1934. Biochemical studies on the fibrinolytic activities of hemolytic streptococci. I. Isolation and caracterization of fibrinolysin. J. Exp. Med. 60, 239.

Walker, M. \& Chester, K.

1934. Antistreptolysin content of the blood serum in theumatic fever and rheumatoid arthritis. J. Clin. Inv. 13, 155.

WALLER, E.

1937. Development of antifibrinolytic properties in blood of patients of rheumatic fever, chronic infective arthritis and bacterial endocarditis. J. Clin. Inv. 16,145 . 